\title{
Pregnancy outcomes in grand multiparous patients: a hospital based study from Jammu and Kashmir, India
}

\author{
Asima Afzal*, Neha Mahajan, Nighat Firdous
}

Department of Obstetrics \& Gynaecology, Lalla Ded Hospital, J \& K, Srinagar, India

Received: 16 January 2016

Accepted: 15 February 2016

\author{
*Correspondence: \\ Dr. Asima Afzal, \\ E-mail: drasmamantoo@gmail.com
}

Copyright: (c) the author(s), publisher and licensee Medip Academy. This is an open-access article distributed under the terms of the Creative Commons Attribution Non-Commercial License, which permits unrestricted non-commercial use, distribution, and reproduction in any medium, provided the original work is properly cited.

\begin{abstract}
Background: Grandmultiparity has been associated with adverse outcome for both fetus and mother such as antepartum hemorrhage, malpresentation, caesarean section rate, postpartum hemorrhage, iron deficiency anemia, and a high perinatal mortality rate. The aim of the study was to determine the prevalence of grandmultiparity (women who had delivered five or more times) and to compare the incidence of antenatal, intrapartum and perinatal complications with those of age-matched controls who had delivered two to four times (multiparous).

Methods: A Prospective comparative study was conducted with 40,250 patients who delivered between 2013 and 2015 in Lalla Ded Hospital Srinagar, Jammu and Kashmir. 2,320 grand multiparous patients who delivered during this period were compared with 2,501 ages matched multiparous patients.

Results: Significant association was found between grandmultiparity and adverse pregnancy outcomes such caesarean delivery, fetal macrosomia, pregnancy induced hypertension and post-partum hemorrhage. A higher incidence of antenatal anaemia was found in grandmultiparous patients than multiparous controls.

Conclusions: Grandmultiparity is associated with increased incidence of medical and obstetric complications.
\end{abstract}

Keywords: Pregnancy, Grandmultiparous, Multiparous

\section{INTRODUCTION}

Grand multiparity, as per the International Federation of Gynaecology and Obstetrics, is the delivery of the fifth to ninth infant, whereas women who are undergoing their tenth (or more) delivery are considered to be great-grandmultiparas. ${ }^{1-5}$ Grandmultiparity has been considered an independent factor for increasing adverse outcome for both fetus and mother specially diabetes mellitus, antepartum haemorrhage, malpresentation, caesarean section rate, postpartum haemorrhage, iron deficiency anaemia, and a high perinatal mortality rate. ${ }^{6}$ Numerous obstetric complications have been independently associated with progressive maternal age. ${ }^{7}$ This prospective study was conducted in LD hospital in Srinagar (Jammu and Kashmir), which has a very high intake of patients and caters a very large region of Kashmir. The purpose of this study was to evaluate the parity related complications during pregnancy and labour in the grand multiparas and to compare them with the age matched controls of multiparous patients.

\section{METHODS}

All grand multiparous women who delivered after 28 weeks of gestation during a 3 year period (1 January 2012 to December 2014) at the LD Hospital, Srinagar served as study group. The control group consisted of the next agematched ( \pm 1 year) multipara (Para 2-4).

Socioeconomic factors were recorded and classified according to the revised Kuppaswamy scale. ${ }^{8}$ Obstetric complications and neonatal morbidity for both groups was recorded. Maternal variables assessed included diabetes mellitus, hypertensive disorders of pregnancy, premature rupture membrane, placental abruption, placenta previa, of medical problems (such as asthma, epilepsy and hypothyroidism), postpartum haemorrhage, 
tears, caesarean hysterectomy, preterm labor, mode of delivery and post term labor. Each of these variables was analysed against each group. For clarity, medical problems included (asthma, epilepsy and hypothyroidism) and diabetes included both pre-existing and gestational diabetes. Macrosomia is defined as fetal weight greater or equal to $4 \mathrm{~kg}$. Fetal variables assessed were Admission to nursery, small for gestational age, fetal death, Apgar score, fetal weight, gestational age at delivery, fetal distress and macrosomia. Each of the fetal complications was assessed against each group.

\section{Statistical analysis}

The Statistical Package for the Social Sciences (SPSS 17 or Windows) was used for recording and statistical analyses of data. The descriptive statistics used included the mean, the frequency distribution and the standard deviation. A chi-square test was used to compare the means of qualitative data, whereas a Student's t-test was used to compare the means of quantitative data. In multivariate analysis, all independent variables were added to the model at the same time.

The test of significant was set at a $\mathrm{p}<0.005$.

\section{RESULTS}

Table 1: Age distribution of grand multipara and multipara patients.

\begin{tabular}{|c|c|c|c|}
\hline $\begin{array}{l}\text { Age } \\
\text { (Years) }\end{array}$ & Grand multipara & Multipara & p value \\
\hline$<25$ & $70(3.01 \%)$ & $175(6.9 \%)$ & 0.01 \\
\hline $25-29$ & $232(10 \%)$ & $401(16.03 \%)$ & 0.01 \\
\hline $30-34$ & $534(23.01 \%)$ & $1450(57.9 \%)$ & 0.00 \\
\hline $\begin{array}{l}35 \text { and } \\
\text { more }\end{array}$ & $1484(63.96 \%)$ & $475(18.9 \%)$ & 0.00 \\
\hline Total & 2320 & 2501 & \\
\hline
\end{tabular}

Table 2: Socio-economic status according to Kuppaswamy scale.

\begin{tabular}{|lll|}
\hline & $\begin{array}{l}\text { Grand } \\
\text { multipara } \\
(\mathrm{n}=2320)\end{array}$ & $\begin{array}{l}\text { Multipara } \\
(\mathrm{n}=2501)\end{array}$ \\
\hline Upper & $10(0.39 \%)$ \\
\hline Upper Middle & $5(0.21 \%)$ & $15(0.59 \%)$ \\
\hline $\begin{array}{l}\text { Middle/lower } \\
\text { middle }\end{array}$ & $622(26.81 \%)$ & $776(31 \%)$ \\
\hline $\begin{array}{l}\text { Lower/Upper } \\
\text { lower }\end{array}$ & $812(35 \%)$ & $800(31.9 \%)$ \\
\hline Lower & $881(37.97 \%)$ & $900(35.9 \%)$ \\
\hline
\end{tabular}

The total number of deliveries during the study period was 40,250 of these 2320 were grand multiparas. Thus, the prevalence of grand multiparity was $5.76 \%$. Majority $(63.96 \%)$ of grand multiparous belonged to age group of
35 years and more whereas higher number of multiparous belonged to age group of 30-34 years. There was significant difference in age distribution in both the groups (Table 1). Majority of patients belonged to middle /lower middle, lower/ upper lower, lower groups of socio economic status according to Kuppaswamy scale in both the groups. No significant difference was seen in socio economic status between the two groups (Table 3). Majority $(45 \%)$ of grand multiparous patients were parity of 5 and majority $(57.3 \%)$ of multiparous were parity of 2 (Table 2).

Table 3: Distribution with regard to parity.

\begin{tabular}{|lll|}
\hline Para & $\begin{array}{l}\text { Grand multipara } \\
\mathbf{n = 2 3 2 0}\end{array}$ & $\begin{array}{l}\text { Multipara } \\
\text { n=2501 }\end{array}$ \\
\hline 1 & & \\
\hline 2 & & $1433(57.3 \%)$ \\
\hline 3 & & $817(32.7 \%)$ \\
\hline 4 & & $251(10 \%)$ \\
\hline 5 & $1044(45 \%)$ & \\
\hline 6 & $698(30.08 \%)$ & \\
\hline 7 & $348(15 \%)$ & \\
\hline 8 & $185(7.9 \%)$ & \\
\hline 9 & $47(2.02 \%)$ & \\
\hline 10 & & \\
\hline 11 & & \\
\hline 12 & & \\
\hline
\end{tabular}

Table 4: Complications of pregnancy.

\begin{tabular}{|c|c|c|c|}
\hline & $\begin{array}{l}\text { Grand } \\
\text { multipara } \\
\mathbf{n}=2320\end{array}$ & $\begin{array}{l}\text { Multipara } \\
\mathrm{n}=2501\end{array}$ & $\begin{array}{l}\mathrm{p} \\
\text { value }\end{array}$ \\
\hline $\begin{array}{l}\text { Anaemia }(\mathrm{Hb}< \\
10 \mathrm{~g} \%)\end{array}$ & $\begin{array}{l}1578 \\
(68.01 \%)\end{array}$ & $\begin{array}{l}1200 \\
(47.98 \%)\end{array}$ & 0.02 \\
\hline \multicolumn{4}{|c|}{ Hypertensive disease } \\
\hline Chronic HTN & $232(10 \%)$ & $301(12.03 \%)$ & 0.5 \\
\hline $\mathrm{PIH}$ & $372(16.03 \%)$ & $352(14.07 \%)$ & 0.4 \\
\hline PET & $279(12.02 \%)$ & $249(9.9 \%)$ & 0.12 \\
\hline $\begin{array}{l}\text { Multiple } \\
\text { pregnancy }\end{array}$ & $139(5.9 \%)$ & $175(6.9 \%)$ & 0.3 \\
\hline \multicolumn{4}{|c|}{ Antepartum haemorrhage } \\
\hline Placenta previa & $163(7 \%)$ & $200(7.9 \%)$ & 0.17 \\
\hline $\begin{array}{l}\text { Abruptio } \\
\text { placenta }\end{array}$ & $139(5.9 \%)$ & $75(2.9 \%)$ & 0.02 \\
\hline Malpresentation & $348(15 \%)$ & $101(4.03 \%)$ & 0.01 \\
\hline IUD & $74(3.2 \%)$ & $92(3.6 \%)$ & 0.6 \\
\hline Diabetes & $134(5.8 \%)$ & $46(1.8 \%)$ & 0.03 \\
\hline $\begin{array}{l}\text { Weight of baby } \\
<2.5 \mathrm{~kg}\end{array}$ & $64(2.8 \%)$ & $66(2.6 \%)$ & 0.7 \\
\hline $\begin{array}{l}\text { Fetal } \\
\text { macrosmia }\end{array}$ & $180(7.8 \%)$ & $57(2.3 \%)$ & 0.01 \\
\hline
\end{tabular}

$\mathrm{HTN}=$ Hypertension; $\mathrm{PIH}=$ pregnancy induced hypertension; PET $=$ Pre eclamptic toxaemia; IUD= Intrauterine death. $P$ value $<0.05$ significant 
Anaemia $(\mathrm{Hb}<10 \mathrm{~g} \%)$ was present in $1578(68.01 \%)$ of grand multiparous patients as compared to $1200(47.98 \%)$ of multiparous patients, which was statistically significant (p value 0.03 ) (Table 4).

Table 5: Method of delivery.

\begin{tabular}{|llll|}
\hline & $\begin{array}{l}\text { Grand } \\
\text { multipara } \\
\text { n=2320 }\end{array}$ & $\begin{array}{l}\text { Multipara } \\
\text { n=2501 }\end{array}$ & p value \\
\hline $\begin{array}{l}\text { Normal vaginal } \\
\text { delivery }\end{array}$ & $\begin{array}{l}1556 \\
(67 \%)\end{array}$ & $\begin{array}{l}2006 \\
(80.2 \%)\end{array}$ & 0.04 \\
\hline Vacuum & $48(2 \%)$ & $26(1 \%)$ & 0.8 \\
\hline Forceps & $24(1 \%)$ & $27(1 \%)$ & 0.6 \\
\hline $\begin{array}{l}\text { Laparotomy/ } \\
\text { hysterectomy }\end{array}$ & $34(1.4 \%)$ & $30(1.1 \%)$ & 0.7 \\
\hline LSCS & $673(29 \%)$ & $\begin{array}{l}366 \\
(14.6 \%)\end{array}$ & 0.02 \\
\hline
\end{tabular}

LSCS $=$ lower segment caesarian section

Chronic hypertension was seen in 232(10\%) cases in grand multiparous as compared to 301(12.03\%) in multiparous patients. No significant difference was seen between both the groups. Pregnancy induced hypertension (PIH) was seen in $372(16.03 \%)$ of grand multiparous patients as compared to 352 (14.07\%) of multiparous patients. No significant difference was seen between the both groups.

Pre eclamptic toxaemia (PET) was seen in 279 (12.02\%) of grand multiparous patients as compared to 249 (9.9\%) of multiparous patients. No significant difference was seen between the two groups.

Table 6: Post-partum complications.

\begin{tabular}{|llll|}
\hline & $\begin{array}{l}\text { Grand } \\
\text { multipara } \\
\text { n=2320 }\end{array}$ & $\begin{array}{l}\text { Multipara } \\
\text { n=2501 }\end{array}$ & p value \\
\hline PPH & $417(17.9 \%)$ & $275(10.9 \%)$ & 0.1 \\
\hline $\begin{array}{l}\text { Wound } \\
\text { disease }\end{array}$ & $12(0.51 \%)$ & $10(0.4 \%)$ & 0.7 \\
\hline UTI & $185(7.9 \%)$ & $175(6.9 \%)$ & 0.5 \\
\hline $\begin{array}{l}\text { Puerperal } \\
\text { sepsis }\end{array}$ & $14(0.61 \%)$ & $13(0.51 \%)$ & 0.6 \\
\hline Shock & $10(0.43 \%)$ & $8(0.31 \%)$ & 0.5 \\
\hline $\begin{array}{l}\text { Maternal } \\
\text { death }\end{array}$ & $2(0.086 \%)$ & $1(0.03 \%)$ & 0.6 \\
\hline
\end{tabular}

$\mathrm{PPH}=$ Postpartum hemmoraghe; UTI= urinary tract infection

Multiple pregnancies were seen in 139 (5.9\%) of grand multiparous patients as compared to $175(6.9 \%)$ of multiparous patients. No significant difference was seen between the two groups.

Placenta previa was seen in $163(7 \%)$ of grand multiparous patients as compared to $200(7.9 \%)$ of multiparous patients, which was not significant, however abruption placenta was seen in more patients, $139(5.9 \%)$ of grand multiparous patients as compared to 75(2.9\%) of multiparous patients, which was statistically significant. There was no significant difference in incidence of intrauterine death in both the groups. Diabetes showed similar preponderance in both the groups. Low birth weight of baby was seen more in grand multiparous patients $(4.7 \%)$ as compared to $2.6 \%$ of multiparous patients, which was statistically significant ( $p$ value 0.01 ).

(Table 5) Normal vaginal delivery was seen in more in multiparous patients $(80.2 \%)$ as compared to grand multiparous patients $(67 \%)$, which was statistically significant ( $p$ value 0.01). Incidence of forceps and vacuum delivery were similar in both the groups. Hysterectomy rates were also similar in both the groups. There was higher number of Lower segment caesarean section (LSCS) in grand multiparous patients (29\%) as compared to $14.6 \%$ of multiparous patients, which was statistically significant.

Postpartum haemorrhage was seen in more numbers of patients in grand multiparous group (17.9\%) as compared to $10.9 \%$, which was statistically significant. However no difference was seen in multiparous group in incidence of wound disease, urinary tract infection, puerperal sepsis, shock and maternal death between the two groups (Table 6).

\section{DISCUSSION}

This prospective research of comparing the outcome of the grand multipara women with that of the multipara women was conducted in one of the tertiary health care centres and teaching hospitals of Jammu and Kashmir which provided healthcare services to nearly whole of the Kashmir region and consists mainly of Muslim population. This prospective study was conducted during the period from Jan 2012 to Dec 2014. The number of deliveries, which were conducted during this period, was 40,250. Grand multiparous patients who delivered during this period were compared with multiparous patients. Total number of grand multiparous that delivered during this period was 2320 patients and multiparous were 2501 patients.

The incidence of grandmultiparity in the current study was $5.76 \%$, which was similar to the study done in a developed Muslim country Saudi Arabia by Alsammami. ${ }^{9}$ However higher prevalence of grandmultiparity was reported in developing countries. ${ }^{10,11}$ The low prevalence rate of grandmultiparity in this study can be explained by the high acceptance of family planning even in Muslim population in Kashmir valley due to increase in both the literacy rate and socioeconomic status in last 10 years. The literacy rate increased from $55.52 \%$ to $67.16 \%$ as per census in India and majority of both multiparous and grand multiparous patients belonged to middle or lower socioeconomic status according to Kuppaswamy scale. ${ }^{12}$ Majority of grandmultiparous patients $(63.96 \%)$ were in the age group of 35 years or more, similar to study by 
Alsammamin which $71.24 \%$ grand multiparous were in the age group of 35 years or more. ${ }^{9}$

Grandmultiparity in our study was significantly associated with various complications of pregnancy, which was similar to various previous published studies. ${ }^{10,13-15}$

Anaemia showed an increased incidence in the grand multiparous patients $(68.1 \%)$ as compared to multiparous patients $(47.98 \%)$ similar to other studies. ${ }^{16-19}$

Low socioeconomic class and repeated pregnancies which do not allow sufficient time to replenish their iron stores could be the cause of anaemia as described by various authors. ${ }^{17,18}$

A hypertensive disorder was not significantly associated with grandmultiparous patients as compared to multiparous patients, which was similar to studies by Alsammami and Akwuruoha. ${ }^{9,10}$

However, Rayamajhi reported significant association of hypertensive disorders in pregnancy with grandmultiparity. ${ }^{20}$

There was no significant association of multiple pregnancies between grandmultiparous women than their multiparous controls, which was contradictory to other studies $^{16,17}$.

Abruption of the placenta was more common among the grand multiparas $(5.9 \%)$ as compared to multiparous patients $(2.9 \%)$. Abruptio placenta is a major complication, which is seen, in the grand multiparas. The parity of the patients was considered to be significant factor for the occurrence of placental abnormalities. ${ }^{21,22}$ However, various other studies shows no difference in incidence between the grandmultiparous and multiparous patients which can be attributed to a higher socio economic status, better nutrition and a better knowledge regarding the prenatal care of the people in these developed countries. ${ }^{9,23}$

There was a significantly higher incidence of multiple pregnancies were found in the grandmultiparous women than their multiparous controls as had been reported in other studies. ${ }^{16,17}$ No significant association between grandmultipara and admission to ICU, intrauterine fetal death and low birth weight babies which was similar to study by Alsamami. ${ }^{9}$

Grandmultiparity was associated with a significantly increased incidence of caesarean deliveries than in the multiparous controls (29\% vs $14.6 \%$ ), which was similar to study by Kavitha. ${ }^{24}$ However studies by Alsamami and Akwuruoha found no difference in the rate of caesarean deliveries among grandmultiparae and their age-matched controls. $^{9,10}$ Increased incidence in our study can be attributed to increased incidence of malpresentation, diabetes and fetal macrosomia similar to study by Kavitha. ${ }^{24}$ There was no statistically significant difference in the rate of laparotomies, hysterectomies, and operative vaginal deliveries in the two groups studied. Post-partum complications incidence were similar in the two groups expect for post-partum hemmoraghe which was significantly more in grandmultiparous group ( $p$ value $<0.01)$.

However studies in developed countries with optimal prenatal and intrapartum care have shown no significant difference in the incidence of postpartum, haemorrhage in the grandmultiparous patients. $16,18,25$

\section{CONCLUSIONS}

Grand multiparas are at a greater risk for complications during pregnancy and labour. A good antenatal and postnatal care is required to reduce the risk of serious complications of pregnancy.

\section{ACKNOWLEDGEMENTS}

This work was carried out in collaboration between all authors. All authors read and approved the final manuscript.

\section{Funding: No funding sources}

Conflict of interest: None declared

Ethical approval: The study was approved by the Institutional Ethics Committee

\section{REFERENCES}

1 Babinski A, Kerenyi T, Torok O, Grazi V, Lapinski RH, Bertwitz RL. Perinatal outcome in grand and great grand multipara; the effects of the parity on obstetric factors. American Journal of Obstetrics and Gynecology. 1999;181:669-74.

2 Begum S. Age and parity related problems which affect the outcome of labor in grand multiparous. Pakistan Journal of Medical Research. 2004;42(4):179-84.

3 Asaf KH. Grand multiparous - still on obstetrical challenge? Pakistan Journal of Obstetrics and Gynecology. 1997;10(1-2):24-8.

4 Bugg GJ, Atwal GS, Maresh M.Grandmultipara in a modern setting. British Journal of Obstetrics and Gynaecology. 2002;109(3):249-53.

5 Sara M, Simonsen E, Lyon JL, Alder SC, Varner M. American Journal of Obstetrics and Gynecology. 2005;106(3):454-60.

6 Grandmultiparity: a potential risk factor for adverse pregnancy outcomes. J Reprod Med. 2012;57(12):53-7.

7 Seoud MA, Nassar AH, Usta IM, Melhem Z, Kazma A, Khalil AM. Impact of advanced maternal age on pregnancy outcome. Am J Perinatol. 2002;19(1):1-7.

8 Dudala SR, Rao AR. Kuppuswamy's SocioEconomic Status Scale - a revision of economic 
parameter for 2012 .International Journal of Research \& Development of Health. 2013;1(1):2-4.

9 Alsammani MA, Ahmed SA. Grandmultiparity: Risk Factors and Outcome in a Tertiary Hospital: A Comparative Study. Med Arh. 2015;69(1):38-41.

10 Akwuruoha E, Kamanu C, Onwere S, Chigbu B, Aluka C, Umezuruike C. Grandmultiparity and pregnancy outcome in Aba, Nigeria: a case-control study. Arch Gynecol Obstet. 2011; 283(2): 167-172.

11 Rayis DA, Abbaker AO, Adam I. Maternal and perinatal outcomes of grandmultiparity in Kassala hospital, eastern Sudan. Khartoum Medical Journal. 2011;4(1):554-7.

12 Jammu and Kashmir Population Census data 2011. http://www.census2011.co.in/census/state/jammu+an d+kashmir.html'

13 Yasmeen S, Danielsen B, Moshesh M, Gilbert WM. Is grandmultiparity an independent risk factor for adverse perinatal outcomes? J Matern Fetal Neonatal Med. 2005;17(4):277-80.

14 Rayamajhi R, Thapa M, Pande S. The challenge of grandmultiparity in obstetric practice. Kathmandu Univ Med J (KUMJ). 2006;4(1):70-4.

15 Abasiattai AM, Utuk NM, Udoma EJ, Umoh AV. Grandmultiparity: outcome of delivery in a tertiary hospital in southern Nigeria. Niger $\mathbf{J}$ Med. 2011;20(3):345-8.

16 Nassar AH, Fayyumy R, Saab W, Ghassan M, Usta MI . Grandmultiparas in modern obstetrics. Am J Perinatol. 2006;23(6):345-9.

17 Ozumba BC, Igwegbe AO. The challenge of grandmultiparity in Nigerian obstetric practice. Int $\mathrm{J}$ Gynaecol Obstet. 1992;37:259-64.
18 Bugg GJ, Atwal GS, Maresh M .Grandmultiparae in a modern setting. $\mathrm{Br} \mathrm{J}$ Obstet Gynaecol. 2002;109:249-53.

19 Goldman GA, Kaplan B, Neri A, Hecht-Resnick R, Harel L, Ovidia J . The grandmultipara. Eur J Obstet Gynaecol Reprod Biol. 1995;61:105-9.

20 Rayamajhi R, Thapa M, Pande S. The Challenge of Grandmultiparity in obstetric practice. Kathmandu Univ Med J (KUMJ). 2006;4(1):70-4.

21 Toivonen S, Heinonen S, Anttile M, Kosma VM, Saarikoski S. Reproductive risk factors, doppler findings, and the outcome of affected births in placental abruption. American Journal of Perinatology. 2002;19(8):451-60.

22 Sheiner E, Shohan-Vardi I, Hallak M, Hadar A, Gortzak-Uzan L, Katz M et al. Placental abruption in term pregnancies: clinical significance and obstetric risk factors. Journal of Maternal-Fetal and Neonatal Medicine. 2003;13(1):45-9.

23 Fayed HM, Abid SF, Stevens B. Risk factors in extreme grand multiparity. International Journal of Gynecology and Obstetrics. 1993;41(1):17-22.

24 d'souza K, Bhagavath P, Krishnan S. Spectrum of Grand Multiparity. Jour Clin Diag Res. 2011;5(6):1247-50.

25 Toohey JS, Keegan KA, Morgan MA, Francis J, Task S, de Veciana M .The dangerous multipara: fact or fiction? Am J Obstet Gynaecol. 1995;172(2pt1):683-6.

Cite this article as: Afzal A, Mahajan N, Firdous N. Pregnancy outcomes in grand multiparous patients: a hospital based study from Jammu and Kashmir, India. Int J Reprod Contracept Obstet Gynecol 2016;5:788-92. 